\title{
Paracondylar process of the occipital bone of the skull: a rare congenital anatomical variant
}

\author{
Ramakrishna Narayanan, Balasubramanyam Shankar, Samir Mustaffa Paruthikunnan, \\ Chaitanya Dattatray Kulkarni
}

Department of Radiodiagnosis, Kasturba Medical College, Manipal University, Manipal, Karnataka, India

\section{Correspondence to} Dr Ramakrishna Narayanan, drrkris@gmail.com

Accepted 28 September 2014

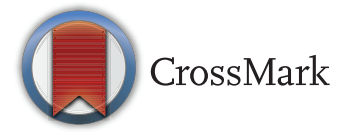

To cite: Narayanan $R_{\text {, }}$ Shankar B,

Paruthikunnan S M, et al. BMJ Case Rep Published online: [please include Day Month Year] doi:10.1136/ bcr-2014-205315

\section{DESCRIPTION}

A 35-year-old male polytrauma patient's cervical spine was evaluated by CT. Coronal (figure 1), axial (figure 2) and volume rendered (figure 3) CT images showed conical bony protuberances arising from the paracondylar area on both sides of the occiput and extending inferiorly to articulate with the superior aspect of the transverse process of atlas bilaterally. The imaging findings are typical of paracondylar processes.

A paracondylar process is a developmental variation owing to incomplete assimilation of proatlas somite into the occiput. ${ }^{1}$ It is a rare developmental anomaly with only a few cases reported in the medical literature. ${ }^{2}$ It can be unilateral or bilateral and is usually asymptomatic. ${ }^{3}$ It is often detected incidentally, as in our case.

Large paracondylar processes can sometimes be symptomatic, especially when they fuse or articulate with the transverse process of atlas and limit

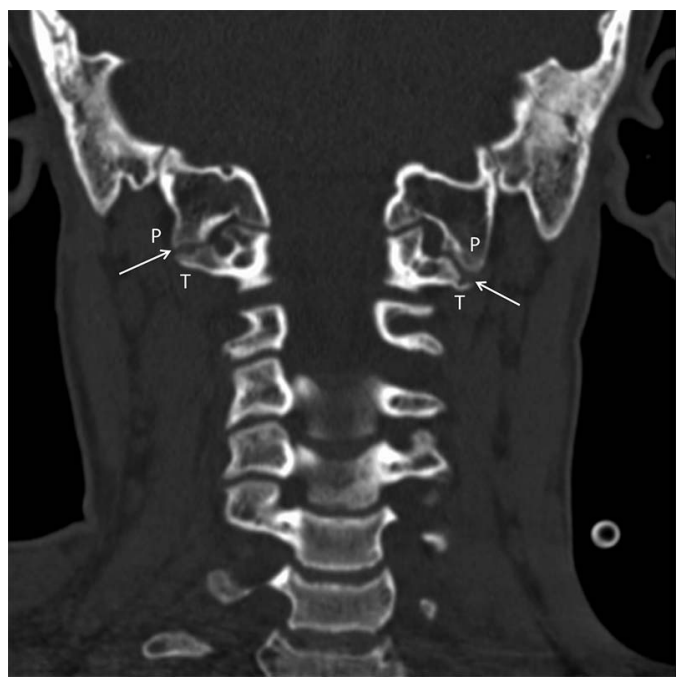

Figure 1 Coronal-reformatted CT showing bilateral paracondylar processes $(\mathrm{P})$ arising from the paracondylar area of the occiput and extending inferiorly to articulate (white arrows) with the superior aspect of transverse process $(\mathrm{T})$ of atlas.

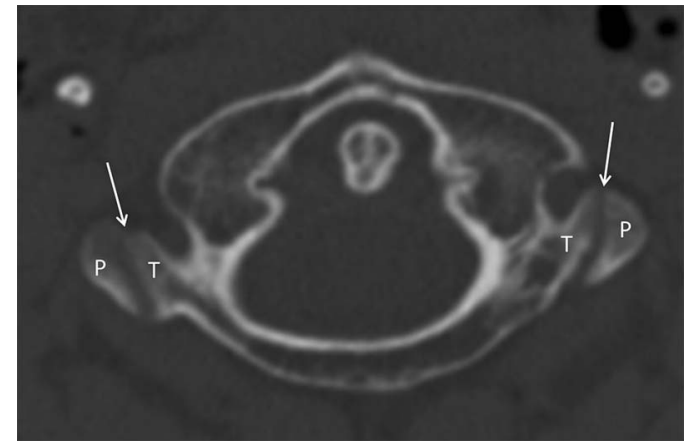

Figure 2 Axial CT showing bilateral paracondylar process $(P)$ articulating (white arrows) with the transverse process $(T)$ of the atlas.

the atlanto-occipital motion. The process may sometimes act as a shim and manifest as skeletal torticolis. ${ }^{3}$ It is in close proximity to the $\mathrm{C} 1 \mathrm{cer}$ vical nerve root and can potentially lead to compression and occipitocervical pain. ${ }^{4}$

The anomaly is often missed on anteroposterior and lateral cervical radiographs because of superimposed anatomical structures. However, on coronalreformatted CT images, the extent and location of this anomalous bridge is well depicted. ${ }^{3}$ A calcified stylohyoid ligament can mimic this anomaly, but is typically a more slender structure and is directed medially. ${ }^{3}$

\section{Learning points}

- A paracondylar process of the occipital bone of the skull is a rare developmental anomaly.

- When symptomatic, this anomaly can present with limitation of neck movements, skeletal torticollis or occipitocervical pain.

- Although it is often missed on conventional cervical radiographs due to superimposed anatomical structures, it is well depicted on coronal-reformatted CT images. 
Images in...

Figure 3 Volume rendered CT demonstrating bilateral paracondylar processes $(P)$ articulating with the transverse processes $(T)$ of the atlas.

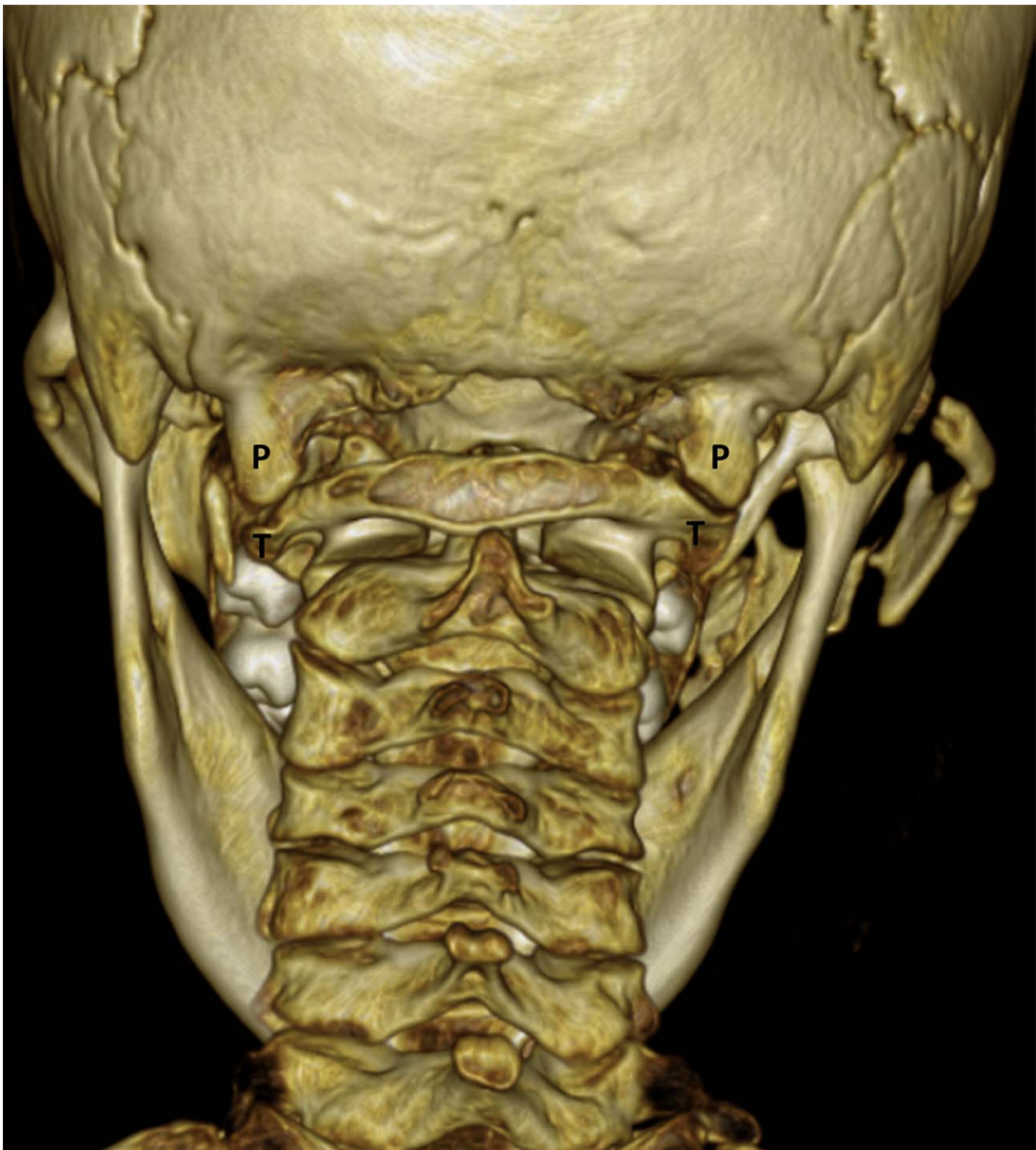

Competing interests None.

Patient consent Obtained.

Provenance and peer review Not commissioned; externally peer reviewed.

\section{REFERENCES}

1 Kaushal P. Epitransverse process: a rare outgrowth from atlas vertebra. Int J Anat Variations 2010;3:108-9.
2 Nolet PS, Friedman L, Brubaker D. Paracondylar process: a rare cause of craniovertebral fusion: a case report. J Can Chiropr Assoc 1999:43: 229-35.

3 Guebert GM, Rowe LJ, Yochum TR, et al. Congenital anomalies and normal skeletal variants. In: Yochum TR, Rowe LJ, eds. Essentials of skeletal radiology. 3rd edn. Lippincott Williams \& Wilkins, 2005:262-4.

4 McCall T, Coppens J, Couldwell W, et al. Symptomatic occipitocervical paracondylar process. J Neurosurg Spine 2010;12:9-12.

Copyright 2014 BMJ Publishing Group. All rights reserved. For permission to reuse any of this content visit

http://group.bmj.com/group/rights-licensing/permissions.

BMJ Case Report Fellows may re-use this article for personal use and teaching without any further permission.

Become a Fellow of BMJ Case Reports today and you can:

- Submit as many cases as you like

- Enjoy fast sympathetic peer review and rapid publication of accepted articles

- Access all the published articles

- Re-use any of the published material for personal use and teaching without further permission

For information on Institutional Fellowships contact consortiasales@bmjgroup.com

Visit casereports.bmj.com for more articles like this and to become a Fellow 